\title{
MPP: A New Look for a New Millennium
}

Medical Principles and Practice (MPP) has taken on a new look starting with this issue to reflect its coverage of research in all the health sciences. When the first issue was published in 1988, the Health Sciences Centre of Kuwait University consisted only of the faculties of Medicine and Allied Health Sciences and Nursing, and the publications in MPP reflected this. Since then, the faculties of Dentistry and Pharmacy have been added. The new cover reflects this expansion and that $M P P$ is now a comprehensive health sciences journal with publications covering all health and related research areas. The larger format conforms to current international standards for scientific journals.

Since its inception 13 years ago, the journal has made significant strides in its international recognition. It is now listed in Science Citation Index, and last year its impact factor surpassed that of 11 other journals. Many manuscripts are now received from countries outside the Gulf region, reflecting a greater awareness and recognition of the journal internationally. It remains the policy of the journal to have all manuscripts internationally peer-reviewed to ensure the highest possible scientific and ethical standard for the papers accepted for publication. We appreciate and acknowledge the support of those who have contributed to the journal's current achievements and status.

Farida Al-Awadi, Editor-in-Chief

\begin{tabular}{ll}
\hline KARGER & ( 2001 S. Karger AG, Basel \\
1011-7571/01/0101-0001\$17.50/0 \\
$\begin{array}{l}\text { Fax +41613061234 } \\
\begin{array}{l}\text { E-Mail karger@karger.ch } \\
\text { www.karger.com }\end{array}\end{array}$ & $\begin{array}{l}\text { Accessible online at: } \\
\text { www.karger.com/journals/mpp }\end{array}$
\end{tabular}

